\title{
Factors governing macrozoobenthic assemblages in perennial springs in north-western Switzerland
}

\author{
S. von Fumetti ${ }^{1, *}$, P. Nagel ${ }^{1}$, N. Scheifhacken ${ }^{2} \&$ B. Baltes ${ }^{1}$ \\ ${ }^{1}$ Institute of Environmental Sciences/Biogeography, University of Basel, St. Johanns-Vorstadt 10, 4056 Basel, Switzerland \\ ${ }^{2}$ Institute of Limnology, University of Konstanz, Mainaustr. 252, 78464 Konstanz, Germany \\ (*Author for correspondence: Tel.: +41-612670817; E-mail: Stefanie.Vonfumetti@unibas.ch)
}

Received 29 June 2005; in revised form 27 March 2006; accepted 1 April 2006; published online 20 June 2006

Key words: macrozoobenthic assemblages, substrate, discharge, typology, springs

\begin{abstract}
Springs are important freshwater habitats that provide refuge for many rare species. In this study, the fauna and abiotic parameters of 20 perennial springs in north-western Switzerland were investigated. Correlation of abiotic and macrozoobenthos data showed that physicochemical parameters had little impact on macrozoobenthic composition, whereas specific substrate parameters strongly influenced the composition of the macrofauna. Surprisingly, nonmetric multidimensional scaling did not reveal a grouping of springs with similar substrate composition or macrozoobenthic assemblages. However, discharge was identified as the factor significantly determining substrate and the composition of macroinvertebrate assemblages. This justifies the hypothesis that, variation in discharge is the disturbance factor governing the macrofaunal composition temporally and spatially within and between patches.
\end{abstract}

\section{Introduction}

Springs are an interface between surface and groundwater (Williams, 1991; Webb et al., 1998). They provide unique habitats for many rare species (Lindegaard et al., 1998; di Sabatino et al., 2003) and for relict species that have survived in an environment of rather stable ambient conditions (Hynes, 1970; Ito, 1998). The few investigations of spring ecosystems in Switzerland were mostly conducted in the early 20th century (Bornhauser, 1912; Chappuis, 1924; Geijskes, 1935). The only recent comprehensive studies of macroinvertebrate assemblages in springs in Switzerland are those of Zollhöfer (1999), who developed a spring typology based on the work of Steinmann (1915) and Thienemann (1924).

Previous investigations assumed that springs are habitats with nearly stable physical and chemical conditions (Odum, 1957; van der Kamp,
1995). Thermal stability has been thought to be one of the main characteristics of springs and the reason for the presence of cold stenothermic animals (Illies, 1952; Erman \& Erman, 1995). However, springs differ in their geomorphological features and their water supply from deep or shallow groundwater. Conditions in springs also change on a temporal scale (Bohle, 1995). Within a spring and between springs, these variabilities lead to a patchy environment with fluctuating conditions for small, isolated populations as described in the patch dynamics concept (Pickett \& White, 1985; Townsend, 1989).

Various chemical factors have been identified to influence the specific spring fauna (Glazier, 1991; Williams et al., 1997; Hahn, 2000; Orendt, 2000). And also substrate composition has been regarded as important (Bonettini \& Cantonati, 1996; Hahn, 2000; Ilmonen \& Paasivirta, 2005). Besides these factors governing the specific spring 
fauna discharge has been identified to influence macrozoobenthic spring assemblages, especially with regard to its temporal variation (Minshall, 1968; Gümbel, 1976; Danks \& Williams, 1991; Smith, 2002; Meyer et al., 2003). Its role relative to other parameters is known neither generally nor specifically for landscape units. This study examines the influence of substrate, discharge, and other physical and chemical variables on the distribution of macroinvertebrates in perennial springs in north-western Switzerland. Our goal was to test whether springs of this region are differentiated into distinct groups and to discover which abiotic parameters are decisive factors for determining the composition of macrozoobenthic assemblages in springs.

\section{Study area}

The study area is located around the city of Basel in north-western Switzerland, into the Jura Mountains. The landscape ranges from urban areas near Basel to agricultural areas and forest. The springs are situated between 280 and $630 \mathrm{~m}$ above sea level, with an average altitude of $430 \mathrm{~m}$ above sea level. The geological underground mainly consists of limestone with groundwater of usually high conductivity. The climate is temperate; winters are moderately cold, and summers are warm and wet (Zollhöfer, 1999). After preliminary investigations, 20 relatively undisturbed, perennial springs (Q1-Q20) were selected. Q1-Q7 are situated near the city of Basel, and Q8-Q20 are located in the Jura Mountains, either in the forest or in rural areas (Table 1). The chosen springs included amongst others limesinter-rheocrenes, karst and alluvial springs, as well as two tubed springs.

\section{Materials and methods}

Macroinvertebrates were quantitatively sampled with a Surber sampler $\left(10 \times 10 \mathrm{~cm}=0.01 \mathrm{~m}^{2}\right.$, $600 \mu \mathrm{m}$ mesh width), which was constructed specifically for use in springs of very small size. This novel device allowed the recording of a high percentage of the macrofauna of the total habitat without disturbing the entire spring ecosystem. The mesh width was chosen because the study focused on the macrofauna. Meiofauna and minute groundwater species were only collected accidentally as they will be studied in another survey. Four samples from each spring (exceptions noted below) were taken in autumn 2003 and four were taken in spring 2004 within $10 \mathrm{~m}$ downstream of the spring source. At each site, a total of $0.08 \mathrm{~m} 2$ (8 samples $\times 0.01 \mathrm{~m}^{2}$ ) was sampled, exceptions are for technical reasons sites Q1 (5 samples, $0.05 \mathrm{~m}^{2}$ ), Q4 (6 samples, $0.06 \mathrm{~m}^{2}$ ), Q8 (7 samples, $0.07 \mathrm{~m}^{2}$ ) and Q9 (9 samples, $\left.0.09 \mathrm{~m}^{2}\right)$. All samples were immediately preserved in $70 \%$ ethanol, and subsequently sorted and determined in the laboratory. Turbellaria were separated in the field before preservation to allow live identification. Taxonomically demanding groups (e.g., Chironomidae) were not identified to the species level, and early instar larvae were identified to the most accurate taxonomic level. On each sampling occasion, water temperature $\left({ }^{\circ} \mathrm{C}\right), \mathrm{pH}$ value, conductivity $\left(\mu \mathrm{S} \mathrm{cm}^{-1}\right)$, oxygen concentration $\left(\mathrm{mg}^{-1}\right)$, and oxygen saturation $(\%)$ were recorded in the field using portable meters (Wissenschaftlich-Technische Werkstätten, Weilheim, Germany). After calibration with our own measurements at some springs using the method of Zollhöfer et al. (2000), discharge was assessed by eye and classified into four classes according to Hoffsten \& Malmqvist (2000): 1: $<11 \mathrm{~min}^{-1} ; 2:>1$ and $<51 \mathrm{~min}^{-1} ; 3$ : $>5$ and $<201 \mathrm{~min}^{-1}$; 4 : $>201 \mathrm{~min}^{-1}$. The substrate types (See supplementary material) were categorized into five classes of frequency based on percentage of areal coverage (Hahn, 2000): 0: 0\%; 1: 1-25\%; 2: 26-50\%; 3: 51$75 \% ; 4: 76-100 \%$. Owing to the three-dimensional nature of a streambed on which the substrates lie, usually more than $100 \%$ was obtained.

All statistical analyses were calculated using PRIMER 5.0 (Clarke \& Warwick, 2001). Faunistic and abiotic data were correlated using the BioEnv routine. The Bray-Curtis similarity matrix of square-root-transformed abundance data was compared with the Euclidian distance similarity matrix of the abiotic data. The Spearman rank correlation was used for correlating data. The combination of abiotic variables with the highest $\rho$ value best describes the faunistic distribution ( $\rho$ between 1 and -1 ).

Substrate data were analyzed using principal components analysis. Ordination of the springs was conducted using nonmetric multidimensional 
Table 1. Selected characteristics of the investigated springs Q1-Q20

\begin{tabular}{llllll}
\hline Spring & $\begin{array}{l}\text { Location } \\
\text { (Swiss coordinates) }\end{array}$ & $\begin{array}{l}\text { Altitude above } \\
\text { sea level }(\mathrm{m})\end{array}$ & $\begin{array}{l}\text { Geographical } \\
\text { region }\end{array}$ & $\begin{array}{l}\text { Mode } \\
\text { of outflow }\end{array}$ & $\begin{array}{l}\text { Land } \\
\text { use }\end{array}$ \\
\hline Q1 & $617.000 / 269.650$ & 380 & Dinkelberg & Flowing & Forest \\
Q2 & $618.775 / 268.775$ & 450 & Dinkelberg & Flowing/seeping & $\begin{array}{l}\text { Forest } \\
\text { Q3 }\end{array}$ \\
$618.375 / 268.750$ & 490 & Dinkelberg & Flowing/seeping & Forest \\
Q4 & $618.450 / 269.275$ & 490 & Dinkelberg & Seeping & Forest \\
Q5 & $616.500 / 270.050$ & 300 & Dinkelberg & Flowing & Floodplain forest \\
Q6 & $618.750 / 271.500$ & 380 & Dinkelberg & Artificial pipe & Meadow \\
Q7 & $607.275 / 273.875$ & 280 & Rhine valley & Alluvial spring & Floodplain forest \\
Q8 & $624.275 / 263.725$ & 370 & Jura Mountains & Seeping & Forest \\
Q9 & $624.875 / 263.525$ & 380 & Jura Mountains & Flowing & Forest \\
Q10 & $630.55 / 256.725$ & 430 & Jura Mountains & Flowing & Forest \\
Q11 & $619.75 / 260.350$ & 380 & Jura Mountains & Flowing & Forest \\
Q12 & $618.920 / 260.290$ & 380 & Jura Mountains & Artificial pipe & Edge of forest \\
Q13 & $636.775 / 252.025$ & 630 & Jura Mountains & Flowing & Forest \\
Q14 & $618.900 / 251.375$ & 510 & Jura Mountains & Artificial pipe & Edge of forest \\
Q15 & $619.125 / 251.475$ & 470 & Jura Mountains & Flowing & Edge of forest \\
Q16 & $619.500 / 256.000$ & 470 & Jura Mountains & Flowing & Meadow \\
Q17 & $604.100 / 258.275$ & 450 & Jura Mountains & Flowing & Forest \\
Q18 & $603.975 / 251.000$ & 370 & Jura Mountains & Alluvial spring & Edge of forest \\
Q19 & $601.350 / 251.400$ & 470 & Jura Mountains & Seeping & Forest \\
Q20 & $633.250 / 260.000$ & 530 & Jura Mountains & Artificial pipe & Edge of forest \\
\hline
\end{tabular}

scaling (nMDS). With nMDS, the similarity index can be chosen freely, and only ranks are compared; it does not assume normal distribution. Distances between springs are relative and illustrate similarities between samples. The Bray-Curtis similarity was used as the similarity index. The similarities between samples were analyzed using the analyses of similarities (ANOSIM) procedure, which is analogous to ANOVA, but relies on a similarity matrix and makes few assumptions on data. The higher the global $R$ value, the larger are the differences between samples.

\section{Results}

\section{Physical and chemical variables and substrate composition}

The physical and chemical properties of the springs differed slightly. The water temperature ranged from 8.0 to $13.7^{\circ} \mathrm{C}$ (mean \pm SD: $10.9 \pm 1.6^{\circ} \mathrm{C}$ ). The oxygen concentration ranged from 5.6 to $10.8 \mathrm{mg} \mathrm{l}^{-1}$ (mean \pm SD: $9.0 \pm 1.6 \mathrm{mg} \mathrm{l}^{-1}$ ), and the oxygen saturation ranged from 47 to $102 \%$ (mean \pm SD: $84 \pm 14.7 \%$ ). The conductivity was high; only Q8 had a very low conductivity (mean $\pm \mathrm{SD}: \quad 706 \pm 334 \mu \mathrm{S} \mathrm{cm}^{-1}$ ). Nearly all springs had circum-neutral $\mathrm{pH}(6.6-8.4)$, and the discharge ranged from very low $\left(<11 \mathrm{~min}^{-1}\right)$ in some muddy springs to very high $\left(>201 \mathrm{~min}^{-1}\right)$ in some springs emerging from an artificial pipe (See supplementary table ${ }^{1}$ ).

The BioEnv routine (PRIMER 5.0) showed that physicochemical parameters had little influence on the composition of macrozoobenthic assemblages. The substrate parameters anoxic mud, leaf litter, clay, and cobblestones influenced the composition of the macrozoobenthic communities most ( $\rho=0.559 ; p=0.01)$. Therefore, physicochemical data were not considered in further analyses.

\section{Fauna}

A total of 82 species and higher taxa were recorded from 155 samples. We found on average 20 taxa

\footnotetext{
${ }^{1}$ Electronic supplementary material is available for this article at < http://dx.doi.org/10.1007/s10750-006-0227-8 > and accessible for authorised users.
} 
per spring (range: $12-33$ taxa; $\mathrm{SD}=5.32$ ) with this quantitative sampling, and eight taxa per surber sample (range: $2-20$ taxa; $\mathrm{SD}=3.47$ ).

Gammarus fossarum was very frequent and occurred in almost every spring and every sample. We determined 22 species of trichoptera. Crunoecia irrorata was recorded in 8 springs, but never reached high abundances, whereas Synagapetus dubitans was very frequent in 4 springs and occurred in $50 \%$ of the springs. The groundwater organisms Bythiospeum spp. and Niphargus spp. occurred in 13 and 14 springs, respectively. Nemouridae were found in over $75 \%$ of the springs.

The population density varied greatly and reached over 17,000 individuals $\mathrm{m}^{-2}$ in one spring. Most other springs had population densities of $<5000$ individuals $\mathrm{m}^{-2}$ (mean \pm SD: $8715 \pm 5795$ individuals $\mathrm{m}^{-2}$ ). Insects comprised an average of $61 \%$ of the taxa recorded per spring (41.7-80\%; SD: $10.9 \%$ ).

An ANOSIM showed that the replicates of one spring are significantly more similar than replicates of different springs (global $R=0.762 ; p=0.01$ ). Therefore, we summarized the data of samples of each spring and used the mean value for nMDS and BioENV analyses.

The principal components analysis conducted with the 13 substrate types showed that factors one and two explained 27 and $17 \%$ of the variance, respectively. The first three factors together explained $58 \%$ of the variance. Component one is dominated by coarse substrate on the positive axis and by biotic and fine substrate on the negative axis. Component two is determined positively by lime sinter and plant structures (roots and dead branches) and negatively by macrophytes (Fig. 1).

The springs could not be classified according to the substrate composition using nMDS. Viewing the graph from the left to the right, a gradient becomes apparent of springs with mainly fine substrate and leaf litter to springs with mostly coarse inorganic substrate. Most of the springs are similar according to their substrate composition. ANOSIM $(R=0.3, p=0.0013)$ showed that springs with low discharge $\left(>1\right.$ and $\left.<51 \mathrm{~min}^{-1}\right)$ differ significantly from springs with very high discharge $\left(>201 \mathrm{~min}^{-1}\right)$. Other factors, e.g., physicochemical parameters and the location of the springs, have no influence on the substrate

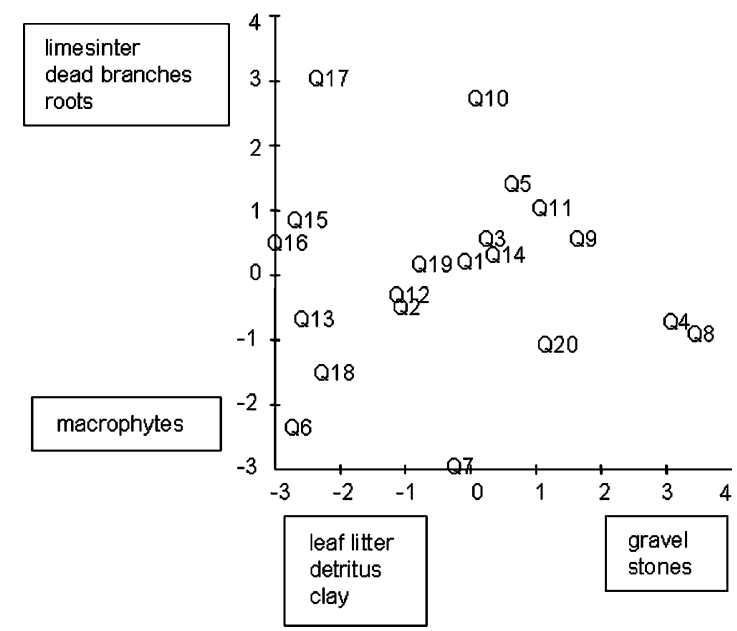

Figure 1. Principal Components Analysis of the substrates recorded in the 20 investigated springs.

composition and the distribution of the springs on the nMDS graph (Fig. 2).

Similar results were obtained when faunistic data were used for nMDS (Fig. 3). Classification was not possible, and ANOSIM $(R=0.4$, $p=0.0001)$ showed that springs with low discharge ( $>1$ and $<51 \mathrm{~min}^{-1}$ ) differ significantly from springs with very high discharge $\left(>201 \mathrm{~min}^{-1}\right)$. Other factors had no significant influence on the macroinvertebrate composition and the distribution of the springs on the nMDS graph.

\section{Discussion}

In Europe, a few attempts have been made to classify springs limnologically (Thienemann, 1924; Schwoerbel, 1959; Gerecke, 1991; Zollhöfer, 1999; Zollhöfer et al., 2000). In our study the investigated springs could not be differentiated into distinct classes. Due to the geological and geographical homogeneity of the area investigated in this study the chemical conditions of the springs were very similar. Only large-scale investigations in springs with different geological settings or investigations in acidified springs (Baltes, 2000; Hahn, 2000) show distinct differences in spring water chemistry.

And also looking at substrate and macroinvertebrate composition we could not differentiate spring types. The transition from one virtual type 


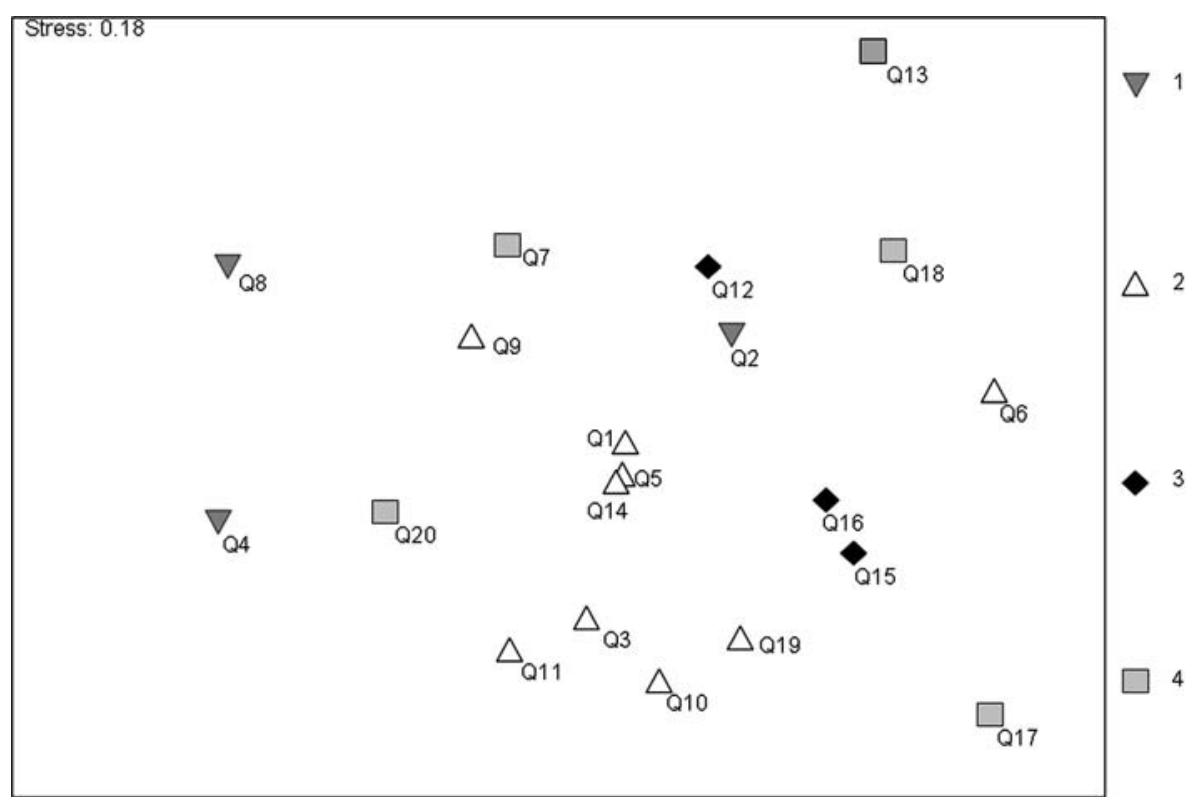

Figure 2. Nonmetric multidimensional scaling (nMDS) of the investigated springs based on the substrate data. Similarity index: BrayCurtis; transformation: square root; factor: discharge $\left(1:<11 \mathrm{~min}^{-1} ; 2:>1\right.$ and $<51 \mathrm{~min}^{-1} ; 3$ : $>5$ and $\left.<201 \mathrm{~min}^{-1} ; 4:>201 \mathrm{~min}^{-1}\right)$.

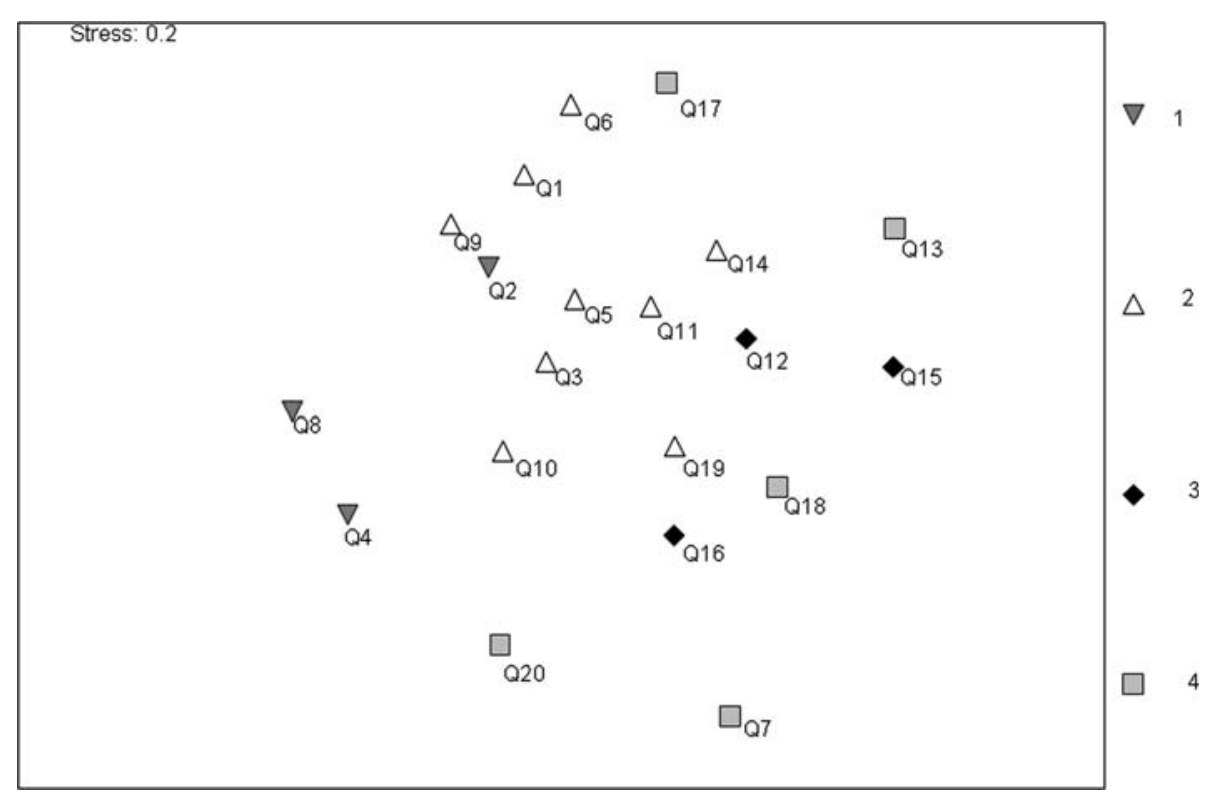

Figure 3. Nonmetric multidimensional scaling (NMDS) of the investigated springs based on the faunistic data. Similarity index: BrayCurtis; transformation: square root; factor: discharge $\left(1:<11 \mathrm{~min}^{-1} ; 2:>1\right.$ and $<51 \mathrm{~min}^{-1} ; 3$ : $>5$ and $<201 \mathrm{~min}^{-1}$; 4 : $\left.>201 \mathrm{~min}^{-1}\right)$.

to another is gradual, and there is almost a continuum between traditional types, such as helocrene and rheocrene (Steinmann, 1915; Thienemann, 1924). In limestone areas, rheocrenes are often sintered to a certain degree, but this is not a discriminating factor and we cannot draw a sharp line between rheocrenes and limesinter-rheocrenes. Nonsintered rheocrenes in other regions might show differences in species composition. For the macroinvertebrate assemblages in the studied 
springs other substrate factors, e.g., leaf litter and cobblestones, are more important. The appearance of a spring and its macroinvertebrate composition depend on many factors, each of which varies considerably. Therefore, approaches to establish regional spring classifications may best reach their goal by describing a continuum with regionally specific forms of emergence, instead of categorizing rigidly distinct types. The individuality of springs has to be considered.

However, our results confirm that substrate composition plays an important role for macroinvertebrate assemblages as it has been widely documented in literature (Bonettini \& Cantonati, 1996; Hahn, 2000; Ilmonen \& Paasivirta, 2005; Gerecke et al., 2005) and it is evident that the substrate composition of a spring influences the diversity of macrozoobenthic communities. Detritivores dominate muddy, helocrene-like springs with low discharge, whereas mostly grazers inhabit springs with coarse substrate and high discharge. Leaf litter is particularly important because of its function as a source of energy in an ecosystem with originally little allochthonous material (RosiMarshall \& Wallace, 2002). Leaf litter is the most common food source, especially for Amphipoda (Cummins et al., 1973). Therefore, it is not surprising that we identified leaf litter as one of the most important substrate components for macrofaunal composition in springs.

As hydrological conditions form spring habitats, discharge is commonly assumed to have an influence on the composition of macrozoobenthic assemblages (Bonettini \& Cantonati, 1996; Hoffsten \& Malmqvist, 2000; Meyer \& Meyer, 2000; Meyer et al., 2003; Ilmonen \& Paasivirta, 2005). Constancy of discharge is particularly important for colonization patterns (Danks \& Williams, 1991; Smith, 2002; Smith et al., 2003). In shaping the substrate and therefore the habitat structure, discharge also affects macrozoobenthic assemblages indirectly (Smith et al., 2003). In the current study, springs with very high discharge could be significantly separated from springs with low discharge with respect to substrate composition and to the composition of macrozoobenthic assemblages. However, the dynamic character of discharge requires long-term studies for assessing the influence of its constancy on macroinvertebrate assemblages.
The periodical changes of abiotic parameters, such as discharge and substrate composition, lead to temporal and spatial patchiness in springs. The patch dynamics concept (Pickett \& White, 1985; Townsend, 1989) has been widely applied to river ecosystems (Downes, 1990; Matthaei \& Townsend, 2000; McCabe \& Gotelli, 2000; Melo et al., 2003). Investigations on the application of the concept to springs are still lacking.

Patch dynamics are strongly connected with the role of disturbance on macroinvertebrate assemblages. The assumption that springs are relatively stable ecosystems leads to the conclusion that disturbance is not an important factor for the dynamics in spring ecosystems. This is consistent with the intermediate disturbance hypothesis, which predicts a peak in biodiversity at an intermediate disturbance level (Connell, 1978) and low diversity at a lower disturbance level, as in the case of springs. Barquin \& Death (2004) support this thesis with the results of their work in northwestern Spain.

However, as we pointed out above, other investigations show the importance of varying discharge for macroinvertebrate communities. As in other running waters, discharge should be the most important disturbance factor in springs, where the span reaches from desiccation in intermittent springs to spates in karst spring systems. Both disturbance events lead to a redistribution of individuals within and between patches of one spring and open up space for new colonists. Because of the periodic disturbance, intermittent springs lack macroinvertebrates with high growth rates in summer or bivoltine, multivoltine or partivoltine animals (Smith \& Wood, 2002), and are usually not inhabited by spring specialists (Gooch \& Glazier, 1991). However, we did not consider intermittent springs in our study. Perennial springs consist of more patches and therefore associated species (Danks \& Williams, 1991) and are refuges for glacial relicts (Fischer et al., 1998; Williams \& Williams, 1998). Also hololimnic species are typical for perennial springs because of their lack of flight dispersal (Gooch \& Glazier, 1991). The present study confirmed that in springs with very low discharge, merolimnic insects are more frequent than hololimnic species. The Amphipod Gammarus fossarum was frequent probably due to the hard water in the investigated springs (Glazier, 1991). 
We can also consider a single spring as a patch of a naturally fragmented spring system at landscape scale with temporal, spatial, and functional aspects. Furthermore, the population of one species in one spring forms a part of a metapopulation as described in the metapopulation concept (Hanski \& Gilpin, 1997). The genetic differentiation within metapopulations will depend on the dispersal abilities of the animals and on isolation factors, such as the distance between adjacent springs. Initial studies show that among insects, the dispersal ability of a species influences the faunal composition of streams (Hoffsten, 2004) and the genetic diversity within a species (Wilcock et al., 2001; Kelly et al., 2002; Miller et al., 2002).

Studying the distribution and dynamics of the characteristic spring fauna will help to identify the most appropriate measures to mitigate adverse man-made effects on springs.

\section{Conclusion}

This study clearly showed the complexity of spring ecosystems. Discharge is one governing factor determining both the substrate composition and the composition of macrozoobenthic assemblages in springs. The springs are also linked because of the influence of the substrate on macroinvertebrate assemblages. Variation in discharge was assumed to be the most important disturbance in springs, where the disturbance may remain predictable over a certain period of time. This would be documented by a characteristic faunal composition. Further investigations will focus on the distribution, disturbance, and dispersal between springs, which are key factors for the dynamics of these unique habitats.

\section{Acknowledgements}

We thank the programme "Mensch Gesellschaft Umwelt" from the University of Basel for funding this project. Thanks to Marko and to the other numerous people who helped with the fieldwork. And we also thank Karen Brune, who improved the language and had helpful comments on the manuscript.

\section{References}

Baltes, B., 2000. Einfluss der Gewässerversauerung auf aquatische Insekten. Mitteilungen der Deutschen Gesellschaft für Allgemeine und Angewandte Entomologie 12: 231-236.

Barquin, J. \& G. Death, 2004. Patterns of invertebrate diversity in streams and freshwater springs in Northern Spain. Archiv für Hydrobiologie 161: 329-349.

Bohle, H. W., 1995. Spezielle Ökologie. Limnische Systeme. Springer Verlag, Berlin, Heidelberg, New York.

Bonettini, A. M. \& M. Cantonati, 1996. Macroinvertebrate assemblages of springs of the River Sarca catchment (Adamello-Brenta Regional Park, Trentino, Italy). Crunoecia 5: 71-78.

Bornhauser, K., 1912. Die Tierwelt der Quellen in der Umgebung Basels. Internationale Revue der Gesamten Hydrobiologie, Biological Supplements 5: 1-90.

Chappuis, P. A., 1924. Die Fauna der unterirdischen Gewässer der Umgebung von Basel. Archiv für Hydrobiologie 14: $1-88$.

Clarke, K. R. \& R. M. Warwick, 2001. Change in Marine Communities. An Approach to Statistical Analysis and Integration. PRIMER-E, Plymouth.

Connell, J. H., 1978. Diversity in tropical rain forests and coral reefs. Science 199: 1302-1310.

Cummins, K. W., R. C. Petersen, F. O. Howard, J. C. Wuycheck \& V. I. Holt, 1973. The utilization of leaf litter by stream detritivores. Ecology 54: 336-345.

Danks, H. V. \& D. D. Williams, 1991. Arthropods of springs, with particular reference to Canada: synthesis and needs for research. In: Williams, D. D. \& H. V. Danks (eds), Arthropods of Springs, with Particular Reference to Canada. Memoirs of the Entomological Society of Canada 155: 203217.

Di Sabatino, A., B. Cicolani \& R. Gerecke, 2003. Biodiversity and distribution of water mites (Acari, Hydrachnidia) in spring habitats. Freshwater Biology 48: 2163-2173.

Downes, B. J., 1990. Patch dynamics and mobility of fauna in streams and other habitats. Oikos 59: 411-413.

Erman, N. A. \& D. C. Erman, 1995. Spring permanence, Trichoptera species richness and the role of drought. Journal of the Kansas Entomological Society Supplement 68: 50-64.

Fischer, J., F. Fischer, S. Schnabel \& H. W. Bohle, 1998. Spring fauna of the Hessian Mittelgebirge: population structure, adaptative strategies, and relations to habitats of the macroinvertebrates, as exemplified by springs in the Rhenisch metamorphic shieldand in the East-Hessian sandstone plate. In Botosaneanu, L. (ed.), Studies in Crenobiology. The Biology of Springs and Springbrooks. Backhuys Publishers, Leiden, 182-199.

Geijskes, D. C., 1935. Faunistisch-ökologische Untersuchungen am Röserenbach bei Liestal im Basler Tafeljura. Beiträge zur Ökologie der Mittelgebirgsbäche. Tijdschrift voor Entomologie 78: 249-382.

Gerecke, R., 1991. Taxonomische, faunistische und ökologische Untersuchungen an Wassermilben aus Sizilien unter Berücksichtigung anderer aquatischer Invertebraten. Lauterbornia 7: 1-304. 
Gerecke, R., F. Stoch, K. Meisch \& I. Schrankel, 2005. Die Fauna der Quellen und des hyporheischen Interstitials in Luxemburg. Ferrantia 41: 139 pp.

Glazier, D. S., 1991. The fauna of North American temperate cold springs: patterns and hypotheses. Freshwater Biology 26: $527-542$.

Gooch, J. L. \& D. S. Glazier, 1991. Temporal and spatial patterns in Mid-Appalachian springs. In Williams, D. D. \& H. V. Danks (eds), Arthropods of Springs, with Particular Reference to Canada. Memoirs of the Entomological Society of Canada 155: 29-49.

Gümbel, D., 1976. Emergenzvergleich zweier Mittelgebirgsquellen (1973). Archiv für Hydrobiologie Supplement 50: 1-53.

Hahn, H. J., 2000. Studies on classifying of undisturbed springs in Southwestern Germany by macrobenthic communities. Limnologica 30: 247-259.

Hanski, I. A. \& M. E. Gilpin (eds), 1997. Metapopulation Biology. Academic Press, San Diego.

Hoffsten, P.-O., 2004. Site-occupancy in relation to flightmorphology in caddisflies. Freshwater Biology 49: 810-817.

Hoffsten, P.-O. \& B. Malmqvist, 2000. The macroinvertebrate fauna and hydrogeology of springs in central Sweden. Hydrobiologia 436: 91-104.

Hynes, H. B. N., 1970. The Ecology of Running Waters. University of Toronto Press, Toronto.

Illies, J., 1952. Die Mölle. Faunistisch-ökologische Untersuchungen an einem Forellenbach im Lipper Bergland. Archiv für Hydrobiologie 46: 424-612.

Ilmonen, J. \& L. Paasivirta, 2005. Benthic macrocrustacean and insect assemblages in relation to spring habitat characteristics: patterns in abundance and diversity. Hydrobiologia 533: 99-113.

Ito, T., 1998. The biology of the primitive, distinctly crenophilic caddisflies, Ptilocolepinae (Trichoptera: Hydroptilidae). A review. In Botosaneanu, L. (ed.), Studies in Crenobiology. The Biology of Springs and Springbrooks. Backhuys Publishers, Leiden, 201-219.

Kelly, L. C., S. D. Rundle \& D. T. Bilton, 2002. Genetic population structure and dispersal in Atlantic Island caddisflies. Freshwater Biology 47: 1642-1650.

Lindegaard, C., K. P. Brodersen, P. Wiberg-Larsen \& J. Skriver, 1998. Multivariate analyses of macrofaunal communities in Danish springs and springbrooks. In Botosaneanu, L. (ed.), Studies in Crenobiology. The Biology of Springs and Springbrooks. Backhuys Publishers, Leiden, 201-219.

Matthaei, C. D. \& C. R. Townsend, 2000. Long-term effects of local disturbance history on mobile stream invertebrates. Oecologia 125: 119-126.

McCabe, D. J. \& N. J. Gotelli, 2000. Effects of disturbance frequency, intensity, and area on assemblages of stream macroinvertebrates. Oecologia 124: 270-279.

Melo, A. S., D. K. Niyogi, C. D. Matthaei \& C. R. Townsend, 2003. Resistance, resilience, and patchiness of invertebrate assemblages in native tussock and pasture streams in New Zealand after a hydrological disturbance. Canadian Journal of Fisheries and Aquatic Sciences 60: 731-739.

Meyer, A. \& E. I. Meyer, 2000. Discharge regime and the effect of drying on macroinvertebrate communities in a temporary karst stream in East Westphalia (Germany). Aquatic Sciences 62: 216-231.

Meyer, A., E. I. Meyer \& C. Meyer, 2003. Lotic communities of two small temporary karstic stream systems (East Westphalia, Germany) along a longitudinal gradient of hydrological intermittency. Limnologica 33: 271-279.

Miller, M. P., D. W. Blinn \& P. Keim, 2002. Correlations between observed dispersal capabilities and patterns of genetic differentation in populations of four aquatic insect species from Arizona White Mountains, U.S.A. Freshwater Biology 47: $1660-1673$.

Minshall, G. W., 1968. Community dynamics of the benthic fauna in a woodland springbrook. Hydrobiologia 32: 305339.

Odum, H. T., 1957. Trophic structure and productivity of Silver Springs, Florida. Ecological Monographs 27: 55-112.

Orendt, C., 2000. The chironomid communities of woodland springs and spring brooks, severely endangered and impacted ecosystems in a lowland region of eastern Germany (Diptera: Chironomidae). Journal of Insect Conservation 4: 79-91.

Pickett, S. T. A. \& P. S. White (eds), 1985. The Ecology of Natural Disturbance and Patch Dynamics. Academic Press, San Diego.

Rosi-Marshall, E. J. \& J. B. Wallace, 2002. Invertebrate foodwebs along a stream resource gradient. Freshwater Biology 47: 129-141.

Schwoerbel, J., 1959. Ökologische und tiergeographische Untersuchungen über die Milben (Acari, Hydrachnellae) der Quellen und Bäche des südlichen Schwarzwaldes und seiner Randgebiete. Archiv für Hydrobiologie, Supplement 24: 385-546.

Smith, H., 2002. The hydro-ecology of limestone springs in the Wye valley, Derbyshire. Journal of the Chartered Institution of Water and Environmental Management 16: 253-259.

Smith, H. \& P. J. Wood, 2002. Flow permanence and macroinvertebrate community variability in limestone spring systems. Hydrobiologia 487: 45-58.

Smith, H., P. J. Wood \& J. Gunn, 2003. The influence of habitat structure and flow permanence on invertebrate communities in karst spring systems. Hydrobiologia 510: 53-66.

Steinmann, P., 1915. Praktikum der Süßwasserbiologie. Bornträger, Berlin.

Thienemann, A., 1924. Hydrobiologische Untersuchungen an Quellen. Archiv für Hydrobiologie 14: 151-190.

Townsend, C. R., 1989. The patch dynamics concept of stream community ecology. Journal of the North American Benthological Society 8: 36-50.

Van der Kamp, R. O., 1995. The hydrogeology of springs in relation to the biodiversity of spring fauna: a review. In Ferrington, L. C. Jr. (ed.), Biodiversity of Aquatic Insects and Other Invertebrates in Springs. Journal of the Kansas Entomological Society. 68: 4-17.

Webb, D. W., M. J. Wetzel, P. C. Reed, L. R. Philippe \& T. C. Young, 1998. The macroninvertebrate biodiversity, water quality, and hydrogeology of ten karst springs in the Salem Plateau of Illinois. In Botosaneanu, L. (ed.), Studies in Crenobiology: The Biology of Springs and Springbrooks. Backhuys Publishers, Leiden, 39-48. 
Wilcock, H. R., A. G. Hildrew \& R. A. Nichols, 2001. Genetic differentiation of a European caddisfly: past and present gene flow among fragmented larval habitats. Molecular Ecology 10: 1821-1834.

Williams D. D., 1991. The spring as an interface between groundwater and lotic faunas and as a tool in assessing groundwater quality. Verhandlungen der Internationalen Vereinigung für Theoretische und Angewandte Limnologie 24: 1621 .

Williams, D. D., N. E. Williams \& Y. Cao, 1997. Spatial differences in macroinvertebrate community structure in springs in southeastern Ontario in relation to their chemical and physical environments. Canadian Journal of Zoology 75: 1404-1414.
Williams, D. D. \& N. E. Williams, 1998. Invertebrate communities from freshwater springs: what can they contribute to applied ecology. In Botosaneanu, L. (ed.), Studies in Crenobiology: The Biology of Springs and Springbrooks. Backhuys Publishers, Leiden, 251-261.

Zollhöfer, J. M., 1999. Spring biotopes in northern Switzerland: habitat heterogenity, zoobenthic communities and colonisation dynamics. Ph.D. Thesis, Swiss Federal Institute of Science and Technology, Zürich.

Zollhöfer, J. M., A. Brunke \& T. Gonser, 2000. A typology of springs in Switzerland by integrating habitat variables and fauna. Archiv für Hydrobiologie Supplement 121: 349-376. 